\title{
SUSTAINABLE TOURISM PRACTICES: A PERCEPTION OF BACKWATER TOURISM DESTINATIONS IN SOUTH KERALA, INDIA
}

\author{
Emilda K. JOSEPH* \\ University of the People, Pasadena, California, USA, e-mail: Emilda.Joseph@uopeople.edu \\ Bindi VARGHESE \\ School of Business and Management, CHRIST (Deemed to be University), \\ Bengaluru, Karnataka, India, e-mail: bindi.varghese@ christuniversity.in \\ Tomy K. KALLARAKAL \\ School of Commerce, Finance and Accountancy, CHRIST (Deemed to be University), \\ Bengaluru, Karnataka, India, e-mail: tomy.kk@christuniversity.in \\ Jose K. ANTONY \\ University of the People, Pasadena, California, USA, e-mail: Jose.Antony@uopeople.edu
}

\begin{abstract}
Citation: Joseph, E.K. Varghese, B., Kallarakal, T.K., \& Antony, J.K. (2021). SUSTAINABLE TOURISM PRACTICES: A PERCEPTION OF BACKWATER TOURISM DESTINATIONS IN SOUTH KERALA, INDIA. GeoJournal of Tourism and Geosites, 38(4), 1232-1238. https://doi.org/10.30892/gtg.38430-764
\end{abstract}

\begin{abstract}
The Tourism Industry in South Kerala focuses more on Houseboat Tourism and Backwater Tourism. The unique, natural features set this destination apart from nearby places, as backwater destinations are rich in numerous natural resources. The sustainable development of these resources will highly enhance the livelihood of the communities in the backwater regions. They will be able to attract tourists seeking unique backwater experiences. Therefore, this article intend $\mathrm{s}$ to comprehend the stakeholders' perceptions on Sustainable Tourism Development in the backwater destinations of South Kerala in India. A total of 277 respondents participated in the research and the study adopted a quantitative research design, while considering the influence of various factors on the Economic, Social and Environmental Sustainability. The data gathered from the study illustrated that the perception of stakeholders about Sustainable Tourism Development varied across different groups. Hence, all the stakeholders in the Tourism Industry need to work together, as this coordination will help to strengthen future development plans, in order to minimize the negative impacts of tourism in the backwater destinations of South Kerala. The study has also identified key turning points that will help to reshape the Sustainable Development of backwater tourism destinations of South Kerala.
\end{abstract}

Key words: sustainable tourism development, sustainable development, backwater tourism, houseboat tourism, stakeholder perception, economic sustainability, social sustainability, environmental sustainability, sustainable tourism practices

\section{INTRODUCTION}

The Tourism Industry lays increased attention to the principles of Sustainable Tourism and this has evolved into an important concept in modern times, in relation to tourism planning and development. With the growth of the Tourism Industry, sustainable tourism products are becoming increasingly relevant for all stakeholders (Hussain et al., 2015) and they have been found to have both positive as well as negative impacts on the community, economy, and the environment. According to Hunter (1997), there are mainly two approaches to Sustainable Tourism - Light Green and Dark Green approaches. The Light Green approach to Sustainable Tourism concentrates on the benefits, expansion and maintenance of tourism activities in the destination, market needs of the products, environmental action and stakeholders' involvement. The Dark Green approach focuses on the economic base, natural resources, environmental impact and training of stakeholders. Many studies have in recent times focused on sustainability as an effective instrument for achieving the highest position that any tourism destination can achieve, by focusing on the three most significant components of Sustainable Tourism, namely the environment, economy and the community (Kimbu and Tichaawa, 2018).

Therefore, if a tourism destination remains unplanned and underdeveloped, it would destroy the economic, environmental, and social aspects of the dependent community (Brokaj, 2014). Hence stakeholder participation in the entire tourism development process and cycle is necessary in order to implement the right values of Sustainable Tourism and achieve sound Sustainable Tourism Development initiatives (Turker et al., 2016). Without the active engagement and commitment of all stakeholders, it will be difficult for local government organizations to develop open and transparent institutional frameworks and share the costs and benefits among all stakeholders in an equal and equitable manner ( $\mathrm{Li}$ and Hunter, 2015). It is also noted that the expertise and experience of all the stakeholders in tourism

\footnotetext{
${ }^{*}$ Corresponding author
} 
management, their participation in the tourism planning and development processes, and their long-term involvement play a significant role in the sustainable management of the tourism destinations. All stakeholders have different expectations and goals regarding the anticipated effects of Sustainable Tourism Development and its efficiency. It is also clear that the performance assessments used in Sustainable Tourism Development should be carried out and investigated from a multistakeholder perspective, so as to try, match, coordinate and maintain the views of all the stakeholders on the predicted Sustainable Tourism Development practices (Sigala, 2014). Therefore, Sustainable Tourism Development cannot be accomplished without considering the interests of all the stakeholders (Moral-Cuadra et al., 2019).

According to UNWTO (1998), a stakeholder refers to "a national or local government with specific competence in tourism matters, tourism establishments and tourism enterprises, including their associations; tourism employees, tourism professionals, and tourism consultants; tourism education and training centres; travellers, including business travellers and visitors to tourism destinations, sites and attractions; and local population and host communities at the tourism destination s through their representatives. Therefore, any group or person who may be affected by the accomplishments of the goals at the tourism destinations can be termed as a stakeholder. Moreover, other interest groups and individuals, especially the residents and the indigenous population, also need adequate recognition as stakeholders.

Stakeholders' interests in their surroundings can affect their preparedness to promote tourism (Gursoy et al., 2002). Understanding stakeholders' perceptions during the various stages of the decision-making processes are seen as an essential strategy for achieving Sustainable Tourism Development. But there is often a lack of involvement of local stakeholders in decision-making, mainly because of very strict legislations and restrictions. Hence stakeholders' perceptions can be considered as an important indicator for measuring Sustainable Tourism Development, as it can be an aid and a significant factor in the growth of any tourism destination. More optimistic perceptions can develop when people have more close and frequent interactions with visitors and when they share more information about tourism (Janusz et al., 2017).

The study therefore concentrates on the perceptions of various stakeholders on Sustainable Tourism Development in the backwater tourism destinations of South Kerala, as they encompass some of the most popular tourism attractions, having won numerous national and international awards. The region offers a wide variety of opportunities to attract tourists, both national and international, because of its extraordinary geographical features. To incorporate Sustainable Tourism into the backwater destinations of South Kerala, an integrated approach to stakeholder participation is necessary. However, the polluted backwaters and the challenges of waste management have become inevitable issues in the region. Today backwater destinations are more than ever before, calling out for an urgent need for Sustainable Tourism Development, in order to minimize the negative impacts of human activities on the destinations.

\section{LITERATURE REVIEWS ON STAKEHOLDER'S PERCEPTIONS ON SUSTAINABLE TOURISM DEVELOPMENT}

Perception can be referred to as the local stakeholders' attitudes towards opinions and reactions. It is commonly known as the relationship between individuals and their surrounding environment (Indrianti, 2016). Perception can influence individuals to act favorably or unfavorably towards their environment ( Aref et al., 2009). The factors that most commonly influence the perceptions of costs and benefits of tourism include the level of local community participation, use of local resources, and the involvement in various tourism activities (Tolvanen et al., 2005). The intensity of these factors can vary depending on the local communities' perceptions about their involvement with the destination and the subsequent impact, whether positive or negative (Núñez-Tabales et al., 2016). Stakeholders are key players in Sustainable Tourism Development and their perceptions are necessary to preserve and sustain tourism products (Manuel et al., 2018). They must also actively participate in solving problems in the destination, by modifying their perceptions and attitude for the successful execution of Sustainable Tourism Development Practices (Reddy, 2020).

Stakeholders' perceptions can to a great extent affect the destination's values, beliefs, and success in terms of Sustainable Tourism Development (Kumar and Nandini, 2013). Stakeholders must focus on their destinations in order to create a more strategic edge, so as to construct a thriving and prosperous tourism industry (Amoako et al., 2021). Their attachment to the destination, tourism experiences, proximity to the tourism centers, personal dependency on tourism, level of involvement in leisure activities, demographic variables such as marital status, age, gender, language, seasonality, tourism taxes, the community's perceived future and the growth stage that the tourism industry is in, will all influence the stakeholders' views on tourism (Brida et al., 2011). All these factors will also play a significant role in decision-making during the planning and policy-making processes (Lee and Hsieh, 2016). Taking into consideration the stakeholders' views will also allow the tourism managers and administrators to adopt more holistic responsive mechanisms towards Sustainable Development. They can be used as important indicators to measure sustainability issues (Eshliki and Kaboudi, 2012) and they can also act as strong guidelines to improve Sustainable Tourism in the destinations.

Indrianti (2016) believes that if a destination completely depends on the Tourism Industry to sustain itself, the local communities in that place will have a major role to play in conserving the area's sustainability through their attitude, perception, support, and involvement, all of which will need to be continuously assessed. But many a time, a very low degree of cooperation exists among the various stakeholders because they have different views of Sustainable Tourism. Local stakeholders do not seem to share the same boundary nor do they seem to be working towards a shared goal, thus undermining the long-term viability of Sustainable Tourism (Bregoli et al., 2016). It has also been found that stakeholders are reluctant to offer their services and financial support to government organizations that are concerned with the sustainability issues (Strydom and Mangope, 2019). Therefore, understanding the stakeholders' perceptions on Sustainable Tourism is very important while trying to relate their support and involvement in various tourism activities. 


\section{THE STUDY AREAS}

The region for the study covers the three major backwater tourism destinations (Figure 1) in South Kerala, namely:

Kottayam: Kumarakom is the widest and the most popular region for Backwater Tourism in the district of Kottayam. It is a vast network of kayals or lakes crisscrossing each other that empty into the largest freshwater lake in South Asia, the Vembanad Lake. This backwater destination offers tourists umpteen experiences of house boats, fishing, and sightseeing.

Alappuzha: This backwater destination is also known as the 'Venice of the East'. Alappuzha is the venue of the worldrenowned Nehru Trophy Snake Boat Races organized in August every year. This exotic destination attracts a large number of tourists through its waterways.

Kollam: The district is one of the major gateways to the majestic backwaters of Kerala. This backwater destination is nestled on the banks of the magnificent Ashtamudi Lake, so-called because of its eight water channels. The lake is the second-largest in Kerala, after Vembanad Lake, and the exotic boat trip between Kollam and Alappuzha is the longest backwater cruise in Kerala connecting these two major lakes.

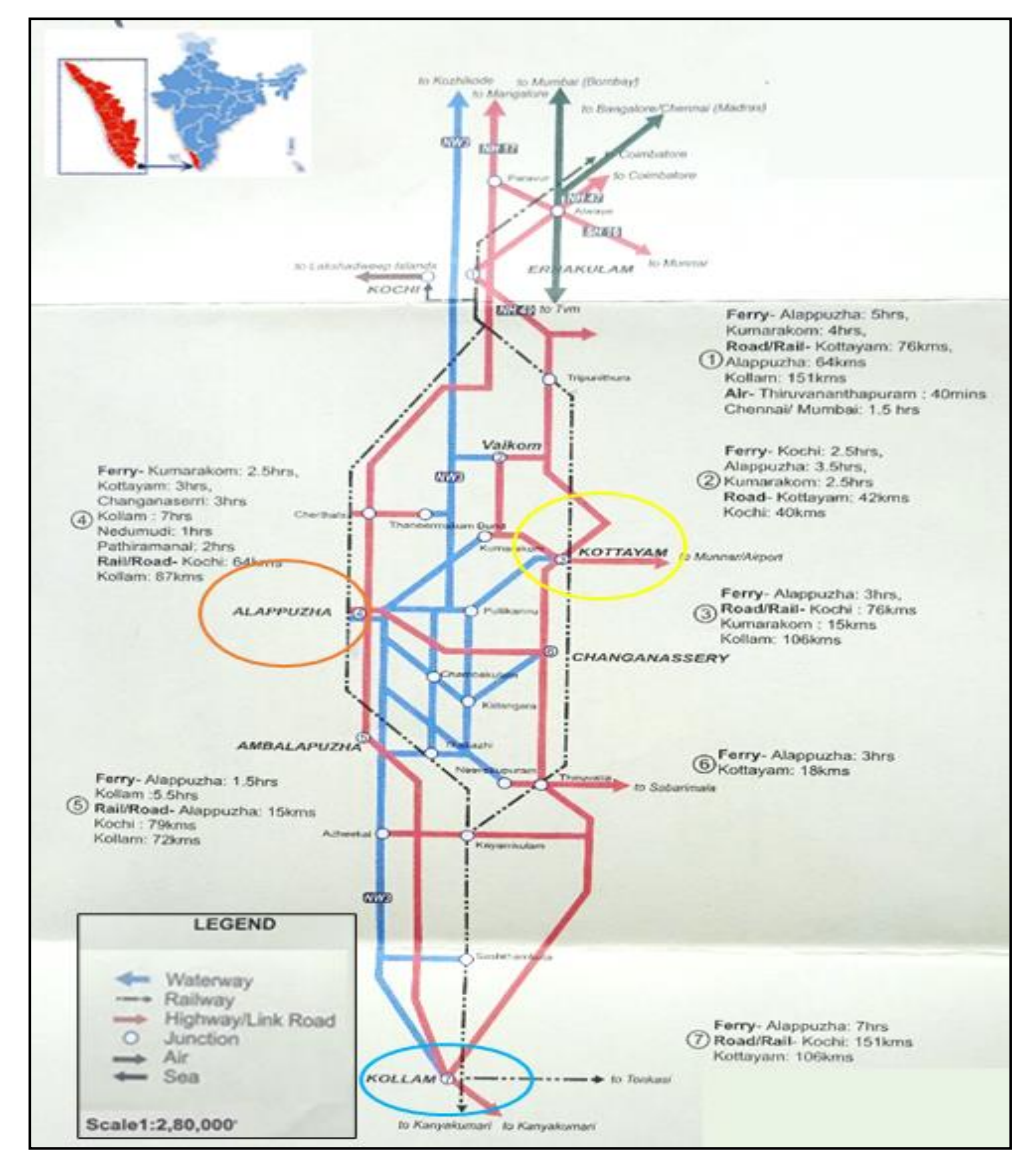

Figure 1. Map of Backwater Tourism Destinations (Source: Authors)

\section{RESEARCH METHODOLOGY}

The first stage of the study involved intense literature surveys, through which the three major destinations within the backwater region of South Kerala were identified. These destinations, namely Kottayam, Alappuzha and Kollam that are involved in Backwater Tourism were stratified, and the study then clustered all the stakeholders in these destinations into public and private players, and they involved the houseboat officials, officials of hotels and resorts, local community members, and government officials. The sample size for each cluster was determined through a Census Survey and Convenience Sampling method. In the second stage, based on thorough reviews of literature, the research gaps were identified. The items that measured the stakeholders' perceptions towards Sustainable Tourism Development were extracted for the preparation of the questionnaire, which used a 5-Point Likert Scale. The reliability of the tool was assessed by examining the Cronbach's Alpha Score. Findings from the reliability test revealed that most of the constructs displayed a score that was higher than the required reliability score, with a Cronbach's Alpha of 0.805 . Once the questionnaire was finalized, a pilot study was conducted before the actual collection of data. By the end of the data collection exercise, a total of 277 samples were collected. In the third stage of the research, the items that measured the stakeholders' perceptions towards Sustainable Tourism Development were input into the analysis tool and software. Descriptive Analysis was used to understand the basic characteristics and responses of the participants. The perception of the stakeholders towards Sustainable Tourism Development at the destinations was analyzed using ANOVA and Tukey Post Hoc Test.

\section{FINDINGS AND DISCUSSIONS FROM THE STUDY}

\section{Profile of the Respondents}

The participants in the survey comprised of $59.9 \%$ males and $40.1 \%$ females. Majority of the respondents were officials who worked in the houseboats (35.7\%) followed by members of the local community (35.4\%), employers and employees of resorts and hotels (24.5\%) and government officials (4.3\%). Focusing on the regions of the respondents, $36.1 \%$ of the respondents belonged to the Kottayam Backwater Region, followed by $33.6 \%$ from the Alappuzha Backwater Region and $30.3 \%$ from the Kollam Backwater Region. Members of the local community, who live close to the destination, can have a profound influence on Sustainable Tourism Development in that destination ( Aref et al., 2009). Hence all the stakeholders from the backwater tourism destinations directly influence Sustainable Tourism Development in the destinations.

Table 1 displays the perceptions of stakeholders on Sustainable Tourism Practices based on the environmental, social and economic constructs in the backwater regions of Kerala.

A good number of the participants in the survey viewed the Environmentally Sustainable Tourism Practices from a positive perspective. The respondents agreed that the conservation of biodiversity and the maximum use of eco-friendly products were the most important Sustainable Tourism Practices employed in the backwater regions. They also ensured that 
tourism could create a large number of job opportunities through these venues. Furthermore, the respondents agreed that the 'implementation of solid waste management plans', 'national legislations and regulations' and 'sustainable constructions' were imperative in order to ensure long-term sustainability management in the backwater destinations. For Socially Sustainable Tourism Practices, majority of the participants agreed that it was necessary to set up clear and mandatory guidelines for socio-cultural sites at destinations and to implement a proper code of conduct for both the members of the local community as well as the guests. Majority of the respondents also agreed that community support is the most important factor in the backwater regions, as it is beneficial and highly critical in developing Socially Sustainable Tourism Practices in the destinations. At the same time, majority of the participants in the survey supported the reduced use of non-disposable goods, as this would help to make the environment cleaner and would certainly attract more tourists to backwater destinations. The most notable contribution of Economically Sustainable Tourism Practices is related to entrepreneurship, especially the encouragement received by local entrepreneurs through more employment opportunities and training. This is true due to the increased economic benefits from houseboat operations and other tourism-related businesses in the backwater regions. Table 2 displays the results of the ANOVA test. ANOVA is used in the study to assess the meaningful differences in the perceptions of different stakeholders about Sustainable Tourism Practices in the backwater destinations of Kerala. It can be inferred from the table that the $p$ values for the Economically Sustainable Tourism Practices and Socially Sustainable Tourism Practices ( $p=0.000$ and $p=0.002$ respectively) are both below 0.05 , which means that there is a statistically significant difference in the perception of various stakeholders on the Economically and Socially Sustainable Tourism Practices. However, no significant difference was observed among the stakeholders on the Environmentally Sustainable Tourism Practices $(p=0.620)$. Being residents of the backwater destinations, all the stakeholders agreed on the Environmentally Sustainable Tourism Practices in the backwater destinations, as they continued to derive maximum personal benefits from tourism.

Table 1. Descriptive analysis on perceptions of stakeholders on sustainable tourism development

\begin{tabular}{|l|l|c|c|}
\hline \multirow{1}{*}{ Variables } & Sustainable Tourism Practices & Mean & $\begin{array}{c}\text { Std. } \\
\text { Deviation }\end{array}$ \\
\hline \multirow{4}{*}{$\begin{array}{l}\text { Environmentally } \\
\text { Sustainable } \\
\text { Tourism } \\
\text { Practices }\end{array}$} & Long Term Sustainability & 3.56 & 1.143 \\
\cline { 2 - 4 } & Legislation & 3.95 & 0.952 \\
\cline { 2 - 4 } & Sustainable Construction & 3.57 & 1.103 \\
\cline { 2 - 4 } & Maximizing Eco-friendly Goods & 4.26 & 0.727 \\
\cline { 2 - 4 } & Solid Waste Management & 4.01 & 1.139 \\
\cline { 2 - 4 } & Harmful Substances & 3.78 & 1.184 \\
\cline { 2 - 4 } & Biodiversity Conservation & 4.49 & 0.735 \\
\hline $\begin{array}{l}\text { Socially } \\
\text { Sustainable } \\
\text { Tourism } \\
\text { Practices }\end{array}$ & Organizational Support & 4.51 & 0.617 \\
\cline { 2 - 4 } & Code of Conduct & 3.34 & 1.274 \\
\cline { 2 - 4 } $\begin{array}{l}\text { Economically } \\
\text { Sustainable } \\
\text { Tourism Practices }\end{array}$ & Guidelines to Guests and & 3.97 & 0.831 \\
\cline { 2 - 4 } & Employees & 4.31 & 0.651 \\
\cline { 2 - 4 } & Encourage Entrepreneurs & 4.32 & 0.933 \\
\cline { 2 - 4 } & Reduce Non-Disposable Goods & 4.30 & 0.743 \\
\hline
\end{tabular}

Table 2. Results of ANOVA

\begin{tabular}{|c|c|c|c|c|c|c|}
\hline \multicolumn{2}{|c|}{ Variables } & $\begin{array}{c}\text { Sum of } \\
\text { Squares }\end{array}$ & df & $\begin{array}{c}\text { Mean } \\
\text { Square }\end{array}$ & F & Sig. \\
\hline \multirow{4}{*}{$\begin{array}{c}\text { Economic } \\
\text { Sustainability }\end{array}$} & $\begin{array}{c}\text { Between } \\
\text { Groups }\end{array}$ & 45.518 & 3 & 15.173 & 22.430 & 0.000 \\
\cline { 2 - 7 } & $\begin{array}{c}\text { Within } \\
\text { Groups }\end{array}$ & 184.670 & 273 & 0.676 & & \\
\cline { 2 - 7 } & Total & 230.189 & 276 & & & \\
\hline \multirow{4}{*}{$\begin{array}{c}\text { Social } \\
\text { Sustainability }\end{array}$} & $\begin{array}{c}\text { Between } \\
\text { Groups }\end{array}$ & 4.755 & 3 & 1.585 & 5.070 & 0.002 \\
\cline { 2 - 7 } & $\begin{array}{c}\text { Within } \\
\text { Groups }\end{array}$ & 85.333 & 273 & 0.313 & & \\
\cline { 2 - 7 } & Total & 90.087 & 276 & & & \\
\hline \multirow{4}{*}{$\begin{array}{c}\text { Environmental } \\
\text { Sustainability }\end{array}$} & $\begin{array}{c}\text { Between } \\
\text { Groups }\end{array}$ & 0.732 & 3 & 0.244 & 0.594 & 0.620 \\
\cline { 2 - 7 } & $\begin{array}{c}\text { Within } \\
\text { Groups }\end{array}$ & 112.282 & 273 & 0.411 & & \\
\cline { 2 - 7 } & Total & 113.014 & 276 & & & \\
\hline
\end{tabular}

Though it is evident that there is a significant difference in the perceptions of different stakeholders about the Economically and Socially Sustainable Tourism Practices, it is not clear which of their perceptions are different. This can be further understood through a Post Hoc Analysis as shown in Table 3.

Table 3.Tukey Post Hoc Test

\begin{tabular}{|c|c|c|c|c|c|c|c|}
\hline \multirow{2}{*}{$\begin{array}{l}\text { Dependent } \\
\text { Variable }\end{array}$} & \multirow{2}{*}{$\begin{array}{l}\text { (I) Type of } \\
\text { Respondents }\end{array}$} & \multirow{2}{*}{$\begin{array}{l}\text { (J) Type of } \\
\text { Respondents }\end{array}$} & \multirow{2}{*}{$\begin{array}{c}\text { Mean } \\
\text { Difference (I-J) }\end{array}$} & \multirow{2}{*}{$\begin{array}{l}\text { Std. } \\
\text { Error }\end{array}$} & \multirow{2}{*}{ Sig. } & \multirow{2}{*}{$\begin{array}{c}\text { 95\% Confidence Interval } \\
\text { Lower Bound }\end{array}$} & \multirow[b]{2}{*}{ Upper Bound } \\
\hline & & & & & & & \\
\hline \multirow{6}{*}{ 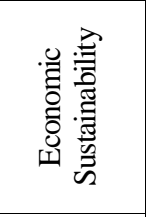 } & \multirow{3}{*}{ Government Officials } & Resort/Hotel Officials & 0.06046 & 0.25752 & 0.995 & -0.7261 & 0.6052 \\
\hline & & House Boat Officials & 0.11869 & 0.2514 & 0.965 & -0.5312 & 0.7685 \\
\hline & & Local Community & $0.87812^{*}$ & 0.25154 & 0.003 & 0.2279 & 1.5283 \\
\hline & \multirow{2}{*}{ Resort/Hotel Officials } & House Boat Officials & 0.17914 & 0.12954 & 0.511 & -0.1557 & 0.514 \\
\hline & & Local Community & $0.93858^{*}$ & 0.12981 & 0.000 & 0.603 & 1.2741 \\
\hline & House Boat Officials & Local Community & $0.75943^{*}$ & 0.1172 & 0.000 & 0.4565 & 1.0624 \\
\hline \multirow{6}{*}{ 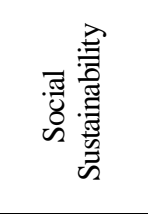 } & \multirow{3}{*}{ Government Officials } & Resort/Hotel Officials & 0.3219 & 0.01750 & 0.257 & -0.1306 & 0.7744 \\
\hline & & House Boat Officials & 0.08249 & 0.1709 & 0.963 & -0.3593 & 0.5242 \\
\hline & & Local Community & 0.34921 & 0.17099 & 0.175 & -0.0928 & 0.7912 \\
\hline & \multirow{2}{*}{ Resort/Hotel Officials } & House Boat Officials & $-0.23940 *$ & 0.08806 & 0.035 & -0.467 & -0.0118 \\
\hline & & Local Community & 0.02731 & 0.08824 & 0.99 & -0.2008 & 0.2554 \\
\hline & House Boat Officials & Local Community & $0.26671 *$ & 0.07967 & 0.005 & 0.0608 & 0.4726 \\
\hline \multirow{6}{*}{ 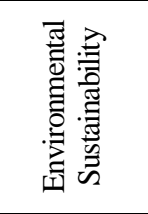 } & \multirow{3}{*}{ Government Officials } & Resort/Hotel Officials & 0.0674 & 0.2008 & 0.987 & -0.4517 & 0.5865 \\
\hline & & House Boat Officials & -0.06566 & 0.19603 & 0.987 & -0.5724 & 0.4411 \\
\hline & & Local Community & -0.02721 & 0.19614 & 0.999 & -0.5342 & 0.4798 \\
\hline & \multirow{2}{*}{ Resort/Hotel Officials } & House Boat Officials & -0.13306 & 0.10101 & 0.553 & -0.3942 & 0.128 \\
\hline & & Local Community & -0.09461 & 0.10122 & 0.786 & -0.3563 & 0.167 \\
\hline & House Boat Officials & Local Community & 0.03845 & 0.09139 & 0.975 & -0.1978 & 0.2747 \\
\hline
\end{tabular}


Post Hoc using Tukey HSD (Honest Significant Difference) Analysis reveals that there is a statistically significant difference in the perceptions on Economically Sustainable Tourism Practices between the government officials and the local community members $(p=0.003)$, the resort officials and the local community members $(p=0.000)$, and the houseboat officials and the local community members $(p=0.000)$. This could be possibly attributed to the increased economic benefits derived from the tourism industry by the government officials, resort officials and the houseboat officials, compared to the members of the local community (Joseph et al., 2020). Similarly, with regard to the Socially Sustainable Tourism Practices, it is found that there is a statistically significant difference in the perceptions between the houseboat officials and the resort officials $(p=0.035)$, which could be because of the possible benefits derived from the tourism industry. There is also a statistically significant difference between the perceptions of the houseboat officials and the local community members $(p=0.005)$, the possible reason for this being that the residents of the destination exhibit more interest and involvement in Socially Sustainable Tourism Practices (Sumarmi et al., 2020).

\section{IMPLICATIONS OF THE STUDY}

The backwater regions of South Kerala continue to face innumerable challenges with the growth of the Tourism Industry. Few of these challenges include the serious problems of improper waste management, pollution, reduction in native fish population, rampant environmental degradation, increase in the number of unregistered houseboats plying in the waters, the lethargic attitude of the local residents and insufficient supply of trained and experienced manpower. The study addressed two such challenges relating to the backwater tourism destinations.

Firstly, it utilized firsthand information from tourism stakeholders in the backwater regions to understand their perception of Sustainable Tourism Development. According to Nadalipour et al. (2019), not seriously considering the stakeholders' perceptions on what the tourism destinations can deliver would inevitably damage the reputation of the destinations and as a result, could downgrade the competitiveness of the destinations, making them unsustainable and easily perishable. Therefore, it is very important to understand the stakeholders' perceptions on Sustainable Tourism Development, so as to increase the benefits of tourism development (Kimbu and Tichaawa, 2018). Findings from the study show that the stakeholders' perceptions on Sustainable Tourism Development remain positive. Stakeholders perceive that sound Sustainable Tourism Practices reduce the use of non-disposable goods, encourage local entrepreneurship, provide more employment opportunities and training, and bring better economic benefits to the region.

Secondly, the study shed light on the conflicting differences in the perceptions of various stakeholders on the social, economic and environmental aspects of sustainability (Table 3). The study identified differences in the perceptions of various stakeholders on the Economically and Socially Sustainable Tourism Practices. The main reasons for the differences could be factors revolving around perceived benefits and costs. Higher involvement of stakeholders through community participation and more number of participative programmes could result in reduced perceived costs and increased perceived benefits (Gursoy et al., 2002). The higher the perceived benefits and lesser the perceived costs, the more enhanced would Sustainable Tourism Development be in the destinations. The study also observed that no significant difference was found among the stakeholders regarding the Environmentally Sustainable Tourism Practices.

Table 3. Conflicting Differences in the Perceptions on Sustainable Tourism Practices in the Backwater Tourism Destinations

\begin{tabular}{|c|l|c|c|c|c|}
\hline $\begin{array}{c}\text { Conflicting Differences } \\
\text { in the Perception }\end{array}$ & \multicolumn{1}{|c|}{ Stakeholders } & $\begin{array}{c}\text { Government } \\
\text { Officials }\end{array}$ & $\begin{array}{c}\text { Local Community } \\
\text { Members }\end{array}$ & $\begin{array}{c}\text { Hotel } \\
\text { Officials }\end{array}$ & $\begin{array}{c}\text { House Boat } \\
\text { Officials }\end{array}$ \\
\hline \multirow{2}{*}{$\begin{array}{c}\text { Economic } \\
\text { Sustainability } \\
\text { Practices }\end{array}$} & Government Officials & - & Yes & No & No \\
\cline { 2 - 6 } & Local Community Members & Yes & - & Yes & Yes \\
\cline { 2 - 6 } & Hotel Officials & No & Yes & - & No \\
\cline { 2 - 6 } & House Boat Officials & No & Yes & No & - \\
\hline \multirow{3}{*}{$\begin{array}{c}\text { Social Sustainability } \\
\text { Practices }\end{array}$} & Government Officials & - & No & No & No \\
\cline { 2 - 6 } & Local Community Members & No & - & No & Yes \\
\cline { 2 - 6 } & Hotel Officials & No & No & - & Yes \\
\cline { 2 - 6 } & House Boat Officials & - & Yes & Yes & - \\
\hline \multirow{2}{*}{$\begin{array}{c}\text { Environmental } \\
\text { Sustainability } \\
\text { Practices }\end{array}$} & Government Officials & - & No & No & No \\
\cline { 2 - 6 } & Local Community Members & No & No & No \\
\cline { 2 - 6 } & Hotel Officials & No & No & - & No \\
\cline { 2 - 6 } & House Boat Officials & No & No & No & - \\
\hline
\end{tabular}

Yes: Differences in the Perception of Stakeholders; No: No difference in the Perception of Stakeholders

The study also has significant practical implications. The findings from the study clearly iterated that there are differences in the perceptions of various stakeholders on the Economically and Socially Sustainable Tourism Practices. Therefore, tourism experts and policymakers can develop sound strategies using this information in order to improve the economic and social sustainability in the destinations. They need to build a distinctive competitive edge to stay successful. One way through which this could be achieved is by encouraging community involvement and community support (Eshliki and Kaboudi, 2012). To connect with and promote such strategies, they could also use different and more contemporary digital and online channels in order to reach out to the younger and more educated population in the region (Amoako et al, 2021). This would also encourage a healthy shift from a top-down to a more participatory approach, and more number of local tourism stakeholders, especially the local community members would get involved in the tourism planning processes (Nguyen et al., 2020). As there is no significant difference in the perceptions among 
the stakeholders concerning the Environmentally Sustainable Tourism Practices, the tourism policy makers need to encourage more environmentally sustainable tourism products, in order to sustain the market profitability and maintain the biodiversity of the regions, especially during the existing challenging time of COVID-19 (Amoako et al., 2021). The above discussions can be summarized through Table 3, which displays the conflicting differences in the perceptions towards Sustainable Tourism Practices in the backwater destinations.

However, this study does have few limitations. The study focused only on the three major backwater tourism destinations in South Kerala. To overcome this drawback, future studies can be carried out on similar research across other backwater destinations. The data for the study was collected only from tourism stakeholders. Considering the perceptions of other stakeholders on Sustainable Tourism Practices is also important. It is a generally accepted theory that the success or failure of tourism growth in any destination depends primarily on the views of the host community (Rasoolimanesh and Seyfi, 2020). Therefore, future studies in the area may include the non-tourism stakeholders as well.

\section{CONCLUSION}

To a great extend the sustainability of tourism growth depends on the degree of support earned from the members of the local community, which in itself is a feature of how these stakeholders view the effects of tourism on their communities (Latip et al., 2018). Therefore, understanding the perceptions of stakeholders have profound importance for the tourism experts and policy makers (Torres-Bagur et al., 2016). The study analyzed the stakeholders' perceptions on Sustainable Tourism Development in the backwater destinations of South Kerala. It concludes that the perceptions of various stakeholders on Sustainable Tourism Development are positive and varied across groups. Majority of the stakeholders are clearly aware that Sustainable Tourism Development creates numerous positive impacts on the local environment, such as the reduced use of non-disposable goods and increased use of eco-friendly products. According to Aref et al. (2009), this positive awareness that is exhibited shows the strong desire of the stakeholders to reduce the negative impacts on tourism destinations. Many stakeholders are of the opinion that this positive awareness could also make the environment cleaner and this would certainly attract more tourists to the backwater destinations, thereby enhancing the tourism-related businesses and economic benefits in the backwater destinations.

Latip et al. (2018) has emphasized that the growth of tourism can provide more monetary incentives for communities in order to maintain their traditional arts and crafts, hotels and other tourism facilities. Local community members should be allowed to engage, involve and promote Sustainable Tourism Development programmes in their regions. In addition to involving the members of the local communities in such programmes, stringent guidelines at the socio-cultural sites should also be enforced and strict codes of conduct must be developed for both the local community members and guests at backwater destinations. Such initiatives could probably encourage more support and involvement from members of the local communities in the tourism development activities. Implementing sound solid waste management plans, introducing national legislations and regulations, and suggesting sustainable ways of construction are imperative to ensure long-term sustainability management practices in the backwater destinations. These could even be considered to be the most effective tools for promoting Sustainable Tourism Development.

Therefore, all the stakeholders in the destination need to engage together, so as to promote and maintain Sustainable Tourism Development (Le, 2018). Facilitation of collaborative practices is one of the central goals of Sustainable Tourism Development, while the lack of satisfaction among stakeholders, with the success of these collaborative practices, could also result in the failure of the Sustainable Tourism Development programmes (Sigala, 2014). Moreover, being residents of the destinations, the local community members need to exhibit keen interest and involvement in the Sustainable Development Practices in their destinations (Akpan and Obang, 2012). Emphasis should be on the economic, social, and environmental benefits by focusing more on tourism-related businesses in the backwater destinations for Sustainable Tourism Development (Basiru et al., 2017). All these initiatives could serve as useful tools in future development plans, so as to reduce the negative impacts on backwater tourism destinations and maximize the benefits of Sustainable Tourism Development initiatives (Nikčević, 2019).

\section{REFERENCES}

Akpan, E.I., \& Obang, C.E. (2012). Tourism: A Strategy for sustainable economic development in Cross River State, Nigeria. International Journal of Business and Social Science, 3(5), 124-129. http://doi.org/10.30845/ijbss

Amoako, G.K., Obuobisa-Darko, T., \& Marfo, S.O. (2021). Stakeholder role in tourism sustainability: The case of Kwame Nkrumah Mausoleum and centre for art and culture in Ghana. International Hospitality Review, 35(1), 1-12. https://doi.org/10.1108/IHR-09-2020-0057

Aref, F., \& Gill, S.S. (2009). Community Perceptions toward Economic and Environmental Impacts of Tourism on Local Communities. Asian Social Science, 5(7), 130-137. https://doi.org/10.5539/ass.v5n7p130

Basiru, H.A., Yacob, M.R., Radam, A., \& Manaf, L.A. (2017). Households' Levels of Awareness, Perception, and Attitude towards Improved Solid Waste Collection Services in Kano. IOSR Journal of Humanities and Social Science, 22(9), 24-36. https://doi.org/10.9790/0837-2209122436

Bregoli, I., Hingley, M., Chiappa, G.D., \& Sodano, V. (2016). Challenges in Italian wine routes: Managing stakeholder networks. Qualitative Market Research: An International Journal, 19(2), 204-224. https://doi.org/10.1108/QMR-02-2016-0008

Brida, J.G., Osti, L., \& Faccioli, M. (2011). Residents' perception and attitudes towards tourism impacts: A case study of the small rural community of Folgaria (Trentino-Italy). Benchmarking: An International Journal, 18(3), 359-385. https://doi.org/10.1108/14635771111137769

Brokaj, R. (2014). Local Government's role in the sustainable tourism development of a destination. European Scientific Journal, 10(31), 103-117. https://doi.org/10.19044/esj.2014.v10n31p\%25p

Eshliki, S.A., \& Kaboudi, M. (2012). Community perception of tourism impacts and their participation in Tourism Planning: A Case Study of Ramsar, Iran. Procedia - Social and Behavioral Sciences, 36(2012), 333-341. https://doi.org/10.1016/j.sbspro.2012.03.037 
Gursoy, D., Jurowski, C., \& Uysal, M. (2002). Resident attitudes - A structural modeling approach. Annals of Tourism Research, 29(1), 79-105. https://doi.org/10.1016/S0160-7383(01)00028-7

Hunter, C. (1997). Sustainable tourism as an adaptive paradigm. Annals of Tourism Research, 24(4), 850-867. http://doi.org/10.1016/S0160-7383(97)00036-4

Hussain, K., Ali, F., Ragavan, N.A., \& Manhas, P.S. (2015). Sustainable tourism and resulting resident satisfaction at Jammu and. Worldwide Hospitality and Tourism Themes, 7(5), 486-499. https://doi.org/10.1108/WHATT-06-2015-0024

Indrianti, N. (2016). Community-based Solid Waste Bank Model for Sustainable Education. Procedia - Social and Behavioral Sciences, 224(August 2015), 158-166. https://doi.org/10.1016/j.sbspro.2016.05.431

Janusz, K., Six, S., \& Vanneste, D. (2017). Building tourism-resilient communities by incorporating residents' perceptions? A photo-elicitation study of tourism development in Bruges. Journal of Tourism Futures, 3(2), 127-143. https://doi.org/10.1108/JTF-04-2017-0011.

Joseph, E.K., Kallarakal, T.K., Varghese, B., \& Antony, J.K. (2020). Sustainable Tourism Development in the Backwaters of South Kerala, India: The Local Government Perspective. Geojournal of Tourism and Geosities, 33(4), 1532-1537. https://doi.org/10.30892/gtg.3

Kimbu, A.N., \& Tichaawa, T.M. (2018). Sustainable development goals and socio-economic development through tourism in central Africa: Myth or reality. GeoJournal of Tourism and Geosites, 23(3), 780-796. https://doi.org/10.30892/gtg.23314-328

Kumar, M., \& Nandini, N. (2013). Community attitude, perception, and willingness towards solid waste management in Bangalore city, Karnataka, India. Internal Journal of Environmental Sciences, 4(1), 87-95. https://doi.org/10.6088/ijes.2013040100009

Latip, N.A., Rasoolimanesh, S.M., Jaafar, M., Marzuki, A., \& Umar, M.U. (2018). Indigenous residents' perceptions towards tourism development: a case of. Journal of Place Management and Development, 11(4), 391-410. https://doi.org/10.1108/JPMD-09-2017-0086.

Le, N.P., Nguyen, T.T.P., \& Zhu, D. (2018). Understanding the Stakeholders' Involvement in Utilizing Municipal Solid Waste in Agriculture through Composting: A Case Study of Hanoi, Vietnam. Sustainability, 10(2314), 1-32. https://doi.org/10.3390/su10072314

Lee, T.H. (2013). Influence analysis of community resident support for sustainable tourism development. Tourism Management, 34(1), 37-46. https://doi.org/10.1016/j.tourman.2012.03.007

Li, Y., \& Hunter, C. (2015). Community involvement for sustainable heritage tourism: a conceptual model. Journal of Cultural Heritage Management and Sustainable Development, 5(3), 248-262. https://doi.org/10.1108/JCHMSD-08-2014-0027

Manuel, J., Mart, G., \& Salinas, A. (2018). An Analysis of the Factors behind the Citizen's attitude of rejection towards tourism in a context of over tourism and economic dependence on this activity. MDPI, 10, 1-18. https://doi.org/10.3390/su10082851

Moral-Cuadra, S., Orgaz-Aüera, F., \& Cañero-Mrales, P.M. (2019). Attitude towards border tourism and its relationship with visitor satisfaction and loyalty. GeoJournal of Tourism and Geosites, 25(2), 609-622. https://doi.org/10.30892/gtg.23314-328

Nadalipour, Z., Hossein, M., Khoshkhoo, I., \& Eftekhari, A.R. (2019). An integrated model of destination sustainable competitiveness. Competitiveness Review: An International Business Journal, 29(4), 314-335. https://doi.org/10.1108/CR-12-2017-0086

Nguyen, H., Van, Diane, L., \& Newsome, D. (2020). Kinh and ethnic tourism stakeholder participation and collaboration in tourism planning in Sapa, Vietnam. Internal Journal of Culture, Tourism and Hospitality Research, 14(4), 579-597. https://doi.org/10.1108/IJCTHR-12-2018-0179.

Nikčević, J. (2019). Strengthening the role of local government to ensure sustainable development of the cruise sector: The case of Kotor. Marine Policy, 109(October), 1-12. https://doi.org/10.1016/j.marpol.2019.103693

Núñez-Tabales, J.M., Canalejo, C., María, A., Tabales, N., Julia, M., Cañizares, S., \& María, S. (2016). Local Community ’ Perceptions on Tourist Impacts and Associated Development: A Case Study on Sal and Boa Vista Islands. Mediterranean Journal of Social Science, 7 (1), 383-394. https://doi.org/10.5901/mjss.2016.v7n1s1p383

Rasoolimanesh, S.M., \& Seyfi, S. (2020). Residents' perceptions and attitudes toward tourism development: a perspective article. Tourism Review, 76 (1), 51-57. https://doi.org/10.1108/TR-11-2019-0461

Reddy, H. (2020). Stakeholder's involvement towards sustaining ecotourism destinations: the case of social entrepreneurship at Stakeholder's involvement towards sustaining ecotourism destinations: The case of social entrepreneurship at Mangalajodi. GeoJournal of Tourism and Geosites, 29(2), 636-648. https://doi.org/10.30892/gtg.29220-495

Sigala, M. (2014). Evaluating the performance of destination marketing systems (DMS): Stakeholder perspective. Marketing Intelligence \& Planning, 32(2), 208-231. https://doi.org/10.1108/MIP-08-2013-0131

Strydom, A.J., \& Mangope, D. (2019). Making community-based tourism sustainable: Evidence from the Free State province, South Africa. GeoJournal of Tourism and Geosites, 24(1), 7-18. https://doi.org/10.30892/gtg. 24101-338

Sumarmi, Kurniawati, E., \& Aliman, M. (2020). Community based tourism (CBT) to establish blue economy and improve public welfare for fishing tourism development in Klatak beach, Tulungagung, Indonesia. GeoJournal of Tourism and Geosites, 31(3), 979-986. https://doi.org/10.30892/gtg.3

Tolvanen, A., Ramet, J., Kinnunen, I., Torn, A., Orell, M., \& Siikamaki, P. (2005). Sustainable tourism. University of Helsinki Department of Forest Ecology Publications, 34(1), 1-10. https://doi.org/http://www.helsinki.fi/mmtdk/mmeko/sunare

Torres-Bagur, M., Palom, A.R., \& Vila-Subiros, J. (2019). Perceptions of climate change and water availability in the Mediterranean tourist sector A case study of the Muga River basin. International Journal of Climate Change Strategies and Management, 11(4), 552-569. https://doi.org/10.1108/IJCCSM-10-2018-0070

Turker, N., Alaeddinoglu, F., \& Can, A.S. (2016). The Role of Stakeholders in Sustainable Tourism Development in Turkey. International Conference on Hospitality, Leisure, Sports, and Tourism - Summer Session, 415-426. http://www.westminster.ac.uk/westminsterresearch.

*** UNWTO. (1998). Guide for local authorities on developing sustainable tourism. World Tourism Organization. https://www.eunwto.org/doi/abs/ 10.18111/9789284402809

Article history: Received: 15.08.2021 Revised: 06.09.2021 Accepted: 08.10.2021 Available online: 26.11.2021 